Jurnal Kependudukan Indonesia | Vol. 15 No. 2 Desember 2020 | 145-164

JURNAL KEPENDUDUKAN INDONESIA

p-ISSN : 1907-2902 (Print)

e-ISSN : 2502-8537 (Online)

\title{
MIGRASI ORANG TUA DAN KOGNITIF ANAK: ANALISIS DATA IFLS 2007 DAN 2014
}

\section{(PARENTAL MIGRATION AND CHILD COGNITIVE: EVIDENCE FROM THE 2007 AND 2014 INDONESIAN FAMILY LIFE SURVEY)}

\author{
Lutvianti Zahra \\ Universitas Indonesia
}

Korespondensi penulis: lutvizahra@gmail.com

\begin{abstract}
Study about migration commonly focuses on the migrants themselves. However, some studies showed that migration also has economic and social impacts on their families, including their children. Cognitive ability is one of the fundamental aspects of child human capital development. This research aims to study the effect of parental migration on children's cognitive ability. This study employs longitudinal data from the Indonesian Family Life Survey (IFLS) in 2007 and 2014 analysed using the Pooled Least Square method and Instrumental Variable Two-Step Least Square (IV $2 S L S)$. Descriptive results show a decline in the average cognitive score of children aged 14-25 years. Moreover, there were no significant differences in cognitive scores between children of migrant parents and non-migrant parents. Inferential results also found that parental migration did not significantly affect children's cognitive ability. Children's cognition is influenced by other characteristics such as age, sex, years of schooling, mother's education, per capita education expenditure, and area of residence.
\end{abstract}

Keywords: parental migration, education, IFLS, cognitive score

\begin{abstract}
Abstrak
Kajian tentang migrasi pada umumnya berfokus pada para migran itu sendiri. Namun, beberapa penelitian menunjukkan migrasi juga memiliki dampak ekonomi dan sosial bagi keluarga dari migran tersebut, termasuk anak-anak mereka. Kemampuan kognitif sebagai salah satu dimensi peningkatan kemampuan manusia yang fundamental. Penelitian ini bertujuan untuk mempelajari pengaruh migrasi orang tua terhadap kemampuan kognitif anak. Penelitian ini menggunakan data longitudinal dari Survei Aspek Kehidupan Rumah Tangga Indonesia (SAKERTI) 2007 dan 2014, yang dianalisis dengan metode Pooled Least Square dan Instrumental Variable Two-Step Least Square (IV 2SLS). Hasil deskriptif menunjukkan terjadinya penurunan pada rata-rata skor kognitif anak usia 14-25 tahun. Lebih lanjut, tidak ada perbedaan yang signifikan pada skor kognitif antara anak dari orang tua migran dan orang tua non-migran. Hasil inferensial juga menunjukkan bahwa migrasi orang tua tidak memiliki pengaruh yang signifikan secara statistik terhadap kognitif anak. Kognitif anak lebih dipengaruhi oleh karakteristik lain seperti umur, jenis kelamin, lama sekolah, pendidikan ibu, pengeluaran pendidikan per kapita, dan daerah tempat tinggal.
\end{abstract}

Kata Kunci: migrasi orang tua, pendidikan, SAKERTI, skor kognitif 


\section{PENDAHULUAN}

Studi mengenai migrasi umumnya difokuskan pada pelaku migran atau subjek migran itu sendiri, namun migrasi juga memiliki dampak sosial ekonomi bagi keluarga migran khususnya anak. Remitansi dari migrasi dapat membantu mengatasi hambatan keuangan yang membatasi pengeluaran atau belanja rumah tangga. Rumah tangga migran mengalokasikan remitansi lebih banyak untuk perumahan, kesehatan, dan pendidikan dan memungkinkan meningkatkan akumulasi modal manusia (Adams \& Cuecuecha, 2010; Wisana, 2012). Modal manusia pada anak tidak terlepas dari peran orang tua baik sebagai pendukung secara finansial (investasi) maupun dalam bentuk psiko-sosial. Modal manusia dalam hal ini pendidikan, dapat terbentuk melalui pendampingan, pengawasan, serta bagaimana orang tua memiliki persepsi mengenai nilai pendidikan sehingga mendorong pencapaian dan hasil pendidikan yang optimal. Pendidikan merupakan salah satu faktor kunci dalam pembentukan modal manusia yang akan berdampak pada pembangunan (Ferrone \& Giannelli, 2015; Kholida, 2018; Psacharopoulos \& Woodhall, 1985).

Indeks Pembangunan Manusia atau Human Development Index (HDI) Indonesia tahun 2018 berada pada peringkat yang menengah yaitu ranking 111 dari 189 negara dengan nilai 0,707 . Peringkat tersebut masih lebih rendah bila dibandingkan dengan negara tetangga lainnya seperti Thailand dan Filipina (United Nation Development Program [UNDP], 2018). Akan tetapi, indikator pendidikan dalam Indeks Pembangunan Manusia menggunakan pengukuran rata-rata lama sekolah yang diharapkan dan rata-rata lama sekolah. Dalam hal ini pendidikan diukur dari segi kuantitas. Jumlah partisipasi sekolah yang meningkat belum dapat menangkap bagaimana mutu atau kualitas pendidikan suatu negara. Kualitas modal manusia belum dapat digambarkan hanya dengan melihat berapa lamanya sekolah.

Lama sekolah (years of schooling) merupakan indikator yang umum diadopsi dalam mengukur pengembangan modal manusia. Namun lama sekolah atau kuantitas sekolah merepresentasikan proksi yang inferior untuk analisis modal manusia (Hanushek \& Woessmann, 2008; Liu, Yu, \& Zheng, 2018; Perezalvarez, 2017; World Bank, 2018). Oleh karena itu, beberapa studi mulai menggunakan pengukuran lain dalam menganalisis perkembangan modal manusia terutama dari segi kualitas yaitu menggunakan kemampuan kognitif. Studi yang dilakukan Hanushek dan Woessmann (2008) menunjukkan bahwa terdapat bukti yang kuat di mana kemampuan kognitif berperan dalam mendorong kesejahteraan ekonomi. Kemampuan kognitif berhubungan erat dengan penghasilan individu, distribusi pendapatan, dan pertumbuhan ekonomi, dibandingkan kuantitas sekolah.

Kemampuan kognitif adalah determinan yang kuat untuk upah, pendidikan, dan partisipasi dalam hal kesuksesan pada berbagai aspek sosial dan ekonomi (Hanushek \& Woessmann, 2008; Heckman, 2007; Murnane, Willet, \& F, 1995). Modal manusia yang disiapkan untuk meningkatkan produktivitas dan daya saing bangsa merupakan syarat untuk dapat memetik bonus demografi pada saat jendela peluang terbuka antara tahun 2020-2030 mendatang (Adioetomo, 2018). Kemampuan kognitif sebagai salah satu dimensi peningkatan kemampuan manusia merupakan bagian yang sangat penting, khususnya dalam perkembangan modal manusia pada anak mengingat anak adalah bagian dari masyarakat dan calon tenaga kerja di masa depan. Terlebih lagi, di era disrupsi dan digital ini kemampuan kognitif merupakan salah satu pengembangan modal manusia yang fundamental untuk menghadapi berbagai tantangan yang ada. Para ekonom berargumen bahwa perkembangan kognitif dan non kognitif adalah hal yang vital untuk hasil pendidikan dan pasar kerja individu untuk jangka panjang.

Aspek kualitas modal manusia khususnya pendidikan biasanya diukur melalui performa anak berupa nilai ujian atau tes murid. Salah satu ujian standar internasional yang juga melibatkan keterampilan kognitif adalah PISA (Programme for International Student Assessment). PISA terdiri dari ujian bahasa, matematika, dan ilmu pengetahuan alam yang berbasis pemecahan masalah yang dilakukan setiap tiga tahun sekali pada anak muda berumur 15 tahun di negaranegara anggota OECD. Pengukuran PISA tidak hanya melihat kemampuan individu dalam mengulangi pengetahuan yang telah diperoleh tetapi juga bagaimana mereka dapat mengekstrapolasikan apa yang telah dipelajari dan mengaplikasikan pengetahuan 
tersebut di lingkungan sekitar baik di dalam maupun di luar sekolah (OECD, 2016).

Indonesia masih berada dalam peringkat yang rendah dalam penilaian keterampilan kognitif dan kualitas pendidikan. Skor PISA Indonesia paling rendah di antara negara-negara Asia lainnya baik pada skor sains, membaca, dan matematika (lihat Gambar 1). Indonesia masih jauh tertinggal dibandingkan Singapura, Tiongkok, Vietnam, dan Thailand. Hasil PISA tahun 2015 menunjukkan Indonesia berada di peringkat ke64 dari 72 negara yang berpartisipasi (OECD, 2016). Hal ini menunjukkan bahwa keterampilan dan kemampuan murid Indonesia dalam hal menerapkan ilmu pengetahuan yang telah dipelajari, memecahkan masalah, dan kesiapan dalam menghadapi situasi di masyarakat modern masih relatif rendah.

Gambar 1. Skor PISA Beberapa Negara di PISA 2015

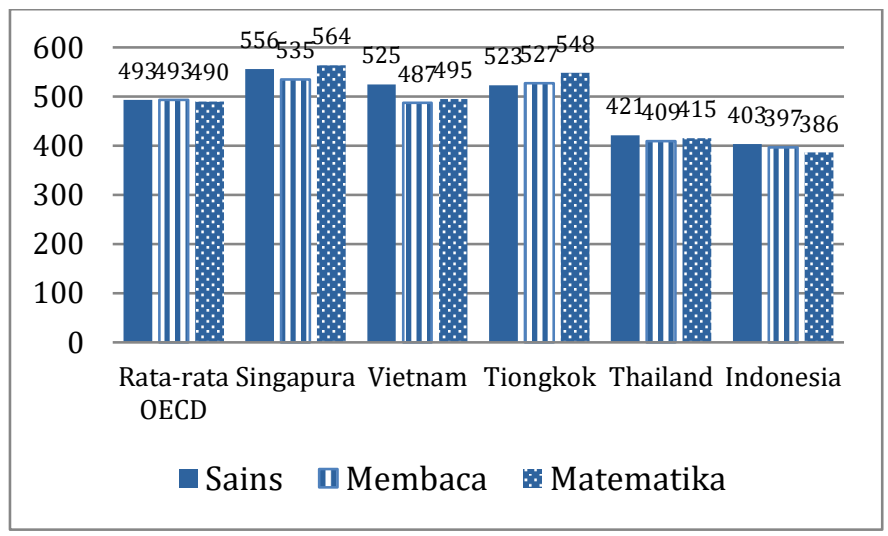

Sumber: OECD (2016)

Kualitas pendidikan, yang secara langsung juga berkaitan dengan kemampuan dan keterampilan kognitif sebagai dasar pembentukan modal manusia, dapat menjadi salah satu indikator bahwa performa modal manusia pada anak perlu mendapatkan perhatian karena merupakan bekal untuk menjadi sumber daya manusia yang berkualitas di masa depan (future labor), lebih produktif, dan berdaya saing.

Kognitif dapat dibangun di sekolah formal, akan tetapi bisa juga datang dari keluarga, teman sebaya, lingkungan sosial, budaya, dan kondisi lingkungan (Hanushek \& Woessmann, 2008; Heckman, 2007; Rutter, 2006; Rutter, Moffitt, \& Caspi, 2006). World Bank (2010) menyebutkan 50\% dari kapasitas kognitif anak dipengaruhi oleh lingkungannya. Oleh karena itu, dalam studi ini kemampuan kognitif anak akan dianalisis menurut status migrasi orang tua sebagai faktor yang memengaruhi dari aspek keluarga, kondisi sosial, dan kondisi lingkungan. Migrasi memungkinkan anak mengalami perubahan sosial dan lingkungan akibat adanya perpindahan tempat tinggal (jika anak ikut bermigrasi bersama orang tua/seluruh anggota keluarga) maupun perubahan dinamika keluarga atau pengasuhan bila anak tidak ikut migrasi (left behind).

Indonesia merupakan salah satu negara berkembang yang mengalami migrasi internal dan internasional skala besar (Hugo, 2002). Indonesia juga disebut sebagai negara berkembang yang mengalami pembangunan dan urbanisasi dengan cepat beberapa dekade belakangan ini (Berbée, 2017). Peningkatan migrasi internal dari tahun ke tahun bukan hanya karena pembangunan yang tidak merata atau ketimpangan wilayah, namun juga karena faktor-faktor seperti keinginan untuk peningkatan tingkat pendidikan yang mendorong pemuda di perdesaan mencari alternatif dari pekerjaan pertanian. Selain itu faktor lain yang membangkitkan emigrasi adalah pembangunan infrastruktur, transportasi publik, komunikasi, peningkatan kepemilikan kendaraan bermotor, meningkatnya komersialisasi dan mekanisasi di pertanian sehingga input tenaga kerja digantikan input modal/kapital, adanya konflik lokal dan regional. Karakteristik Indonesia yang terdiri dari berbagai pulau, suku, dan bahasa juga berperan memengaruhi mobilitas masyarakat di Indonesia, di mana kelompok etnis yang berbeda memiliki kecenderungan untuk pindah (Groppo \& Mendola, 2014).

Banyaknya orang Indonesia yang melakukan migrasi internal, baik antar provinsi maupun dari perdesaan ke perkotaan (rural urban migration), memiliki implikasi secara ekonomi maupun sosial. Implikasi tersebut akan mengarah pada transformasi besar dalam kehidupan dan juga dinamika keluarga karena beberapa anggota keluarga pindah ke tempat lain (Berbée, 2017; Lu, 2014). Akibatnya anak-anak khususnya di negara berkembang semakin terpengaruh oleh migrasi (United Nations International Children's Fund, 2007). Migrasi rumah tangga maupun migrasi individu (orang tua) dapat memengaruhi dalam berbagai aspek termasuk aspek kesejahteraan anak, diantaranya kemampuan dan 
keterampilan kognitif atau pembentukan modal manusia pada anak.

Migrasi dapat memengaruhi pembangunan modal manusia pada anak melalui beberapa jalur seperti melalui remitansi, intra bargaining household, family disruptive effect, informasi dan persepsi atau value akan pendidikan, dan ketidakhadiran orang tua. Remitansi dari migrasi, khususnya migrasi orang tua, dapat memiliki pengaruh positif dalam meningkatkan modal manusia terkait pendidikan anak (Antman, 2012; Catrinescu, dkk., 2011; Hu, 2013; Iqbal, Iqbal, \& Mozmi, 2014; Kandel \& Kao, 2001; Morooka \& Liang, 2009; Nobles, 2011). Namun beberapa studi lain menemukan bahwa terdapat trade-off antara peningkatan pendapatan rumah tangga melalui remitansi dengan ketidakhadiran salah satu anggota rumah tangga akibat migrasi dan menunjukkan hubungan negatif terhadap pendidikan anak baik pencapaian pendidikan maupun performa atau output pendidikan (Cuong \& Linh, 2016; Lee, 2011; Lu, 2014; Zhao, dkk., 2014; Zhou, dkk., 2014). Jika anggota rumah tangga yang bermigrasi adalah orang tua, dapat berdampak pada kurangnya pengawasan dan pendampingan dalam hal pendidikan. Jika hanya salah satu orang tua yang bermigrasi maka orang tua yang tinggal di rumah akan memiliki beban ekstra untuk menjalankan peran pasangannya sehingga mengurangi kontrol atas pengawasan dalam hal pendidikan (Ferrone \& Giannelli, 2015; Iqbal, dkk., 2014; Liu, dkk., 2018). Sementara itu, Gong, Kong, Li, dan Meng (2008) menemukan bahwa performa sekolah anak yang ditinggalkan lebih baik dibandingkan anak yang bermigrasi bersama kedua orang tuanya.

Penelitian ini sedikit berbeda dengan studi-studi sejenis sebelumnya. Studi mengenai pengaruh migrasi orang tua terhadap pengembangan modal manusia pada anak khususnya terkait pendidikan telah banyak dilakukan misalnya pada penelitian Berbée (2017), Cuong dan Linh (2016), Kholida (2018), Liu, dkk. (2018), Lu (2014) dan Zhao, dkk. (2014) namun menunjukkan hasil yang beragam dan belum konklusif. Sebagian besar studi menggunakan lama sekolah (kuantitas) sebagai indikator modal manusia. Sementara itu dari aspek kualitas pendidikan, studi serupa yang pernah dilakukan di Indonesia menggunakan nilai Ujian Nasional untuk mengukur performa anak. Penelitian ini menggunakan indikator modal manusia lain yaitu kemampuan kognitif anak. Bila studi-studi sebelumnya menggunakan data yang bersifat cross-section maka dalam penelitian ini menggunakan data longitudinal atau panel sehingga memiliki kelebihan yaitu dapat melihat riwayat atau status migrasi orang tua pada periode sebelumnya. Selain itu pada penelitian ini juga dapat diketahui transisi skor kognitif anak pada dua periode.

Di Indonesia, semakin tingginya arus migrasi dan berbagai tipe migrasi individu dan rumah tangga memungkinkan terdapat perbedaan dalam kognitif anak. Rumah tangga yang memiliki riwayat migrasi atau rumah tangga migran mungkin berbeda dengan rumah tangga non-migran, performa kognitif anak dari orang tua migran mungkin berbeda dengan anak dari orang tua non-migran. Seluruh anggota keluarga yang bermigrasi atau anak ikut bermigrasi mungkin berbeda dengan anak yang ditinggalkan. Oleh karena itu, penelitian ini bertujuan untuk mempelajari perbedaan rumah tangga migran dengan non-migran terkait kognitif anak, mempelajari pengaruh migrasi orang tua terhadap kognitif anak, dan mempelajari pengaruh variabel-variabel kontrol terhadap skor kognitif anak. Tujuan ini khususnya untuk mengetahui karakteristikkarakteristik lain yang juga memengaruhi skor kognitif anak.

Hubungan migrasi dan pembangunan telah lama mengalami perdebatan sehingga menimbulkan beberapa paradigma di kalangan peneliti seperti pesimisme, optimisme, dan pluralis. Interaksi antara migrasi dan pembangunan termasuk diantaranya bagaimana dampak migrasi, baik itu internal maupun internasional, memengaruhi pembangunan seperti redistribusi pendapatan, pengurangan kemiskinan, pertumbuhan ekonomi di wilayah pengirim migran maupun wilayah tujuan. Begitu pula sebaliknya, bagaimana faktor-faktor pembangunan (developmental) memengaruhi keputusan atau terjadinya migrasi. Terdapat beberapa teori mengenai migrasi dan pembangunan, namun dalam penelitian ini lebih menekankan pada model keputusan level-mikro yaitu teori New Economics of Labor Migration (NELM). Asumsi dalam teori ini adalah migrasi dari negara berkembang merupakan perilaku migran dalam konteks yang lebih luas yaitu mempertimbangkan tidak 
hanya individu namun juga unit yang lebih besar seperti keluarga atau rumah tangga. Teori neoklasik migrasi berpusat pada individu sebagai pembuat keputusan migrasi sementara dalam teori NELM, keluarga dan rumah tangga menjadi faktor utama. Pada umumnya, migrasi adalah strategi rumah tangga untuk diversifikasi risiko dan meningkatkan kesejahteraan ekonomi rumah tangga (Stark \& Bloom, 1985). Dalam konsep NELM, keluarga atau rumah tangga tidak hanya memaksimumkan pendapatan tetapi juga meminimalkan dan menyebarkan risiko. Migrasi internal dan migrasi internasional dianggap sebagai respon rumah tangga dalam menghadapi risiko pendapatan.

\section{Pendekatan Fungsi Produksi Modal Manusia}

Secara teoritis, modal manusia didefinisikan sebagai stok yang terkait dengan faktor-faktor manusia di dalam diri seseorang yang dapat meningkatkan produktivitas seperti keahlian atau kemampuan, kesehatan, kemampuan sosial, dan kreativitas (Becker, 1964). Dalam studi ini fokus pada faktor skill yang biasanya berhubungan dengan pendidikan dan kemampuan kognitif.

Model dasar dari pembangunan modal manusia adalah fungsi produksi modal manusia (human capital production function approach) yang menentukan hubungan dari input dan output (Almond \& Currie, 2011; Behrman, Pollak, \& Taubman, 1982; Heckman, 2007). Pendekatan produksi modal manusia yang mengestimasi output atau hasil pendidikan dan kemampuan kognitif pada umumnya merupakan fungsi dari input keluarga, input orang tua, input sekolah, dan input anak.

\section{METODE}

\section{Sumber Data}

Penelitian ini bersifat kuantitatif dengan menggunakan data sekunder dari Indonesian Family Life Survey (IFLS) atau Survei Aspek Kehidupan Rumah Tangga (SAKERTI). IFLS adalah survei yang berskala besar dan detail mengenai kondisi sosial ekonomi rumah tangga, komunitas, dan fasilitas yang dilakukan di negara berkembang oleh RAND (Research and
Development) yang bekerja sama dengan lembaga penelitian di tiap-tiap survei yang dilaksanakan. Terdapat 13 provinsi yang dicakup dalam IFLS meliputi Sumatera Utara, Sumatera Barat, Sumatera Selatan, Lampung, DKI Jakarta, Jawa Barat, Jawa Tengah, D.I. Yogyakarta, Jawa Timur, Bali, Nusa Tenggara Barat, Kalimantan Selatan, dan Sulawesi Selatan.

Penelitian ini menggunakan data dari survei IFLS karena bersifat longitudinal sehingga bisa ditelusuri riwayat migrasi rumah tangga maupun individu pada gelombang 4 (2007) dan gelombang 5 (2014). Variabel ini dibutuhkan untuk menganalisis perbedaan skor kognitif anak dari rumah tangga migran dan nonmigran. Selain itu, IFLS menyediakan Cognitive Assessment pada Buku EK sehingga dapat mengukur skor kognitif individu yang tidak tersedia pada surveisurvei lain.

Dalam penelitian ini, rumah tangga sampel adalah rumah tangga yang memiliki anggota rumah tangga yang berusia 7-18 tahun pada IFLS 4 dan merupakan individu yang sama yang telah berusia 14-25 tahun pada IFLS 5. Unit analisis dalam penelitian ini adalah anggota rumah tangga yang berusia 7-18 tahun pada IFLS 4 (2007-2008) dan diamati perkembangannya sampai IFLS 5 (2014-2015) berjumlah 2.144 responden.

Variabel terikat yang digunakan dalam penelitian ini adalah kemampuan kognitif anak. Penilaian kognitif yang terdapat di kuesioner IFLS adalah berdasarkan Raven's Progressive Colored Matrices (RPM) berupa tes mengisi bagian yang hilang berdasarkan pola bentuk pada pertanyaan. Bagian tes kognitif ini mengukur perkembangan logika (abstract reasoning) dan merupakan pengukuran level kognitif individu secara umum. Terdapat dua jenis buku tes dalam IFLS yaitu buku EK1 dan EK2. Buku EK1 atau Level 1 diberikan pada responden usia 7-14 tahun yang terdiri dari 12 pertanyaan kognitif dan lima pertanyaan matematika sederhana. Sedangkan buku EK2 atau Level 2 diberikan pada kelompok usia yang lebih tua yaitu 15-24 tahun yang terdiri dari delapan pertanyaan kognitif dan lima pertanyaan matematika dengan tingkat kesulitan yang lebih tinggi dibandingkan pertanyaan di buku EK1. 
Dalam penelitian ini untuk menghitung skor akhir tes kognitif adalah dengan cara menghitung jumlah total jawaban yang benar kemudian dihitung rata-rata dan standar deviasi pada masing-masing level pertanyaan (Level 1 dan Level 2) untuk membentuk z-skor. Skor mentah total dibentuk ke dalam z-skor karena terdapat satu level pertanyaan diberikan pada rentang umur tertentu.

Tabel 1. Variabel-Variabel Penelitian

\begin{tabular}{|c|c|c|}
\hline No. & Variabel & Simbol \\
\hline (1) & $(2)$ & (3) \\
\hline \multicolumn{3}{|c|}{ Variabel Terikat (Y) } \\
\hline 1. & Skor kognitif & cognitive_zscore \\
\hline \multicolumn{3}{|c|}{ Variabel Bebas Utama $(\mathrm{X})$} \\
\hline 2. & Status migrasi orang tua & parental_mig \\
\hline \multicolumn{3}{|c|}{ Variabel Kontrol } \\
\hline 3. & Jenis kelamin anak & child_sex \\
\hline 4. & Umur Anak & child_age \\
\hline 5. & Lama sekolah anak & child_yearsofschool \\
\hline 6. & Pendidikan Ayah & father_educ \\
\hline 7. & Pendidikan Ibu & mother_educ \\
\hline 8. & $\begin{array}{l}\text { Pengeluaran pendidikan } \\
\text { per kapita }\end{array}$ & Educ_expend_month \\
\hline 9. & $\begin{array}{l}\text { Pengeluaran rumah tangga } \\
\text { per kapita }\end{array}$ & Expend_month_cap \\
\hline 10. & $\begin{array}{l}\text { Jumlah anggota rumah } \\
\text { tangga }\end{array}$ & hh_size \\
\hline 11. & Wilayah tempat tinggal & residence \\
\hline
\end{tabular}

Variabel Instrumen (IV) instrumen untuk variabel status migrasi orang tua (parental_mig) pada model 2)
12. Kepemilikan lahan
land_holding

Sumber: IFLS 4 dan IFLS 5

Variabel bebas utama yang digunakan dalam penelitian ini adalah status migrasi orang tua. Dalam IFLS, migrasi didefinisikan sebagai perpindahan ke suatu tempat di luar lokasi tempat tinggal dan tinggal di tempat tersebut lebih dari 6 bulan. Dalam studi ini, rumah tangga migran didefinisikan sebagai rumah tangga yang memiliki minimal satu anggota rumah tangga yang melaporkan pernah melakukan perpindahan atau memiliki riwayat migrasi. Karena analisis dalam penelitian ini berfokus pada migrasi orang tua, maka anak disebut memiliki orang tua migran jika minimal salah satu orang tua, baik itu ibu maupun ayah, pernah melakukan migrasi melintasi batas desa/kelurahan dan tinggal di tempat tujuan minimal 6 bulan. Status migrasi orang tua diamati pada tahun 2007 (IFLS 4) dan tahun 2014 (IFLS 5). Anak yang memiliki orang tua migran kemudian disebut sebagai anak migran. Penelitian ini juga menggunakan beberapa variabel kontrol yang terdiri dari karakteristik anak, karakteristik orang tua, karakteristik rumah tangga, dan karakteristik wilayah. Variabel kontrol karakteristik anak adalah jenis kelamin anak, umur anak, dan lama sekolah. Sementara itu variabel kontrol karakteristik orang tua adalah pendidikan ayah dan pendidikan ibu. Karakteristik rumah tangga adalah pengeluaran pendidikan per kapita, pengeluaran rumah tangga per kapita, dan jumlah anggota dan karakteristik wilayah tempat tinggal. Variabel kepemilikan lahan sebagai variabel instrumen.

\section{Metode Analisis}

Metode analisis yang digunakan dalam penelitian ini adalah analisis deskriptif dan analisis inferensial. Analisis deskriptif memberikan gambaran umum secara statistik seperti distribusi frekuensi, distribusi persentase, nilai rata-rata (mean), median, maupun standar deviasi yang disajikan dalam bentuk tabel, dan grafik untuk menggambarkan karakteristik variabel penelitian. Selain itu, analisis uji beda rata-rata dengan menggunakan independent $t$ test untuk mengetahui perbedaan skor kognitif dan karakteristik lainnya antara anak dari orang tua migran dengan anak dari orang tua non-migran. Analisis inferensial pada penelitian ini menggunakan regresi data panel yaitu pooled least square dengan Instrumental Variable Two-Stage Least Square (IV 2SLS) untuk mengetahui pengaruh migrasi orang tua terhadap kognitif anak. Penelitian ini menggunakan regresi pooled least square karena variabel terikat bersifat numerik dan jenis data yang digunakan adalah data panel di mana estimasi data panel tahun 2007 dan 2014 menjadi satu kesatuan observasi atau digabungkan (pooled). Penelitian ini menggunakan variabel instrumen two-stage least square (IV 2SLS) untuk mengontrol isu endogenitas yang sering ditemui pada studi migrasi.

\section{Independent Sample T-Test}

Penelitian ini menggunakan uji independent sample $t$ test untuk menguji perbedaan rata-rata skor dan karakteristik lain antara dua kelompok yaitu anak migran dan non-migran di mana subjek dari kedua kelompok ini saling bebas (independent). Jika $p$ value 
di bawah 0,05 maka terdapat perbedaan rata-rata antara dua kelompok. Rumus independent sample t-test adalah sebagai berikut:

$t=\frac{X_{1} X_{2}}{\sqrt{\frac{\sum_{i=1}^{n} X_{i 1}^{2}-\frac{\left(\sum_{i=1}^{n} X_{i 1}^{2}\right)^{2}}{n_{1}}+\sum_{i=1}^{n} X_{i 2}^{2}-\frac{\left(\sum_{i=1}^{n} X_{i 2}^{2}\right)^{2}}{n_{2}}}{n_{1} n_{2}\left(1-\frac{2}{n_{1}+n_{21}}\right)}}}$

Keterangan :

$X_{1} \quad$ : Rata-rata pada distribusi sampel 1

$X_{2} \quad$ : Rata-rata pada distribusi sampel 2

$n_{1} \quad$ : Jumlah individu pada sampel 1

$n_{2} \quad$ : Jumlah individu pada sampel 2

$\sum_{i=1}^{n} X_{i 1}^{2}-\frac{\left(\sum_{i=1}^{n} X_{i 1}^{2}\right)^{2}}{n_{1}} \quad$ : Nilai varians pada distribusi sampel 1

$\sum_{i=1}^{n} X_{i 2}^{2}-\frac{\left(\sum_{i=1}^{n} X_{i 2}^{2}\right)^{2}}{n_{2}} \quad$ : Nilai varians pada distribusi sampel 2

\section{Regresi Data Panel}

Analisis inferensial digunakan untuk mengetahui pengaruh migrasi orang tua terhadap kognitif anak. Penelitian ini menggunakan data panel sehingga metode estimasi yang digunakan adalah regresi data panel. Data panel adalah data yang mengkombinasikan data cross section dengan data time series (runut waktu). Data panel dalam penelitian ini termasuk dalam kategori balanced panel karena setiap unit cross sectional memiliki jumlah pengamatan time series yang sama (Gujarati, 2003). Penelitian ini menggunakan regresi data panel pooled least square.

\section{Pooled Least Square}

Model ini sering disebut juga dengan model common effects model. Pada model ini menggabungkan data cross section dan time series (pooled data), kemudian dilakukan pendugaan parameter dengan menggunakan metode OLS (Ordinary Least Square). Penggabungan data pada model ini mengakibatkan perbedaan antar individu maupun antar waktu tidak dapat dilihat. Hal ini karena asumsi perilaku data antar individu sama dalam berbagai kurun waktu atau intersep maupun slope dari model adalah sama. Model ini mengasumsikan bahwa $\alpha$ dan $\beta$ akan sama (konstan) untuk setiap data cross section dan time series. Persamaan model pooled least square dalam penelitian ini adalah sebagai berikut:

Model 1:

Cognitive_score $_{i t}=\beta_{0}+\beta_{1}$ parental_migration $i t+$ $\beta_{2}$ mother_educ $_{i}+\beta_{3}$ father_educ $_{i}+\beta_{4}$ child_sex $_{i}+$ $\beta_{5}$ child_age $_{i t}+\beta_{6}$ child_yearsofschool ${ }_{i t}+\beta_{7}$ hh_size $_{i t}+$ $\beta_{8}$ expend_month ${ }_{i t}+\beta_{9} e d u c \_\exp _{i t}+\beta_{10}$ residence $\left.+\varepsilon_{i t}\right]$

\section{Endogenitas (Endogeneity Treatment)}

Berdasarkan studi-studi sebelumnya, studi mengenai migrasi rentan dengan permasalahan endogenitas. Endogenitas atau adanya variabel endogen dalam persamaan regresi dapat terjadi karena dua hal utama yaitu adanya omitted variable bias dan simultaneous causality bias. Omitted variable bias yaitu ketika ada variabel yang berkorelasi dengan variabel bebas (X) namun tidak teramati sehingga tidak dimasukkan ke dalam regresi. Kemudian simultaneous causality bias adalah variabel bebas atau penjelas yang bersifat endogen di mana $\mathrm{X}$ menyebabkan $\mathrm{Y}$ dan $\mathrm{Y}$ menyebabkan X. Endogenitas membuat estimator yang diperoleh menjadi bias dan tidak konsisten. Permasalahan ini dapat diatasi dengan memasukkan instrumental variabel dan dalam penelitian ini menggunakan teknik regresi two-step least squares $(2 S L S)$.

Variabel instrumen yang digunakan dalam penelitian ini adalah kepemilikan lahan (land holdings). Kepemilikan aset produktif termasuk lahan dapat menjadi motivasi penting untuk tidak bermigrasi atau tinggal bersama dengan anggota keluarga di wilayah asal. Oleh karena itu penelitian ini memasukkan variabel dummy kepemilikan lahan untuk mengetahui indikasi apakah suatu rumah tangga memiliki lahan pertanian atau tidak di desa tempat tinggalnya. Persamaan regresi two-stage least square (IV 2SLS) dapat dituliskan sebagai berikut: 
Tahap 1 (Model 1):

Probit $[\pi(\text { Parental_migration })]_{i t}=\beta_{0}+\beta_{I}$ land_holding ${ }_{i t}+\beta_{5} S D$ sederajat $_{i t}+\beta_{6} S M P$ sederajat $_{i t}+\beta_{7} S M A$ sederajat $_{i t}+\beta_{8}$ Perguruan tinggi $_{i t}+\beta_{9}$ lainnya $_{i t}+$ $\beta_{10}$ expend_month ${ }_{i t}+v_{i t}$; menghitung predicted values Parental_migratıon

(3)

\section{Tahap 2 (Model 2)}

Cognitive_score $_{i t}=\beta_{0}+\beta_{1}$ Parental_mlgratıon $_{i t}+$ $\beta_{2} S D$ sederajat_ibu $u_{i t}+\beta_{3} S M P$ sederajat_ibu $u_{i t}+\beta_{4} S M A$ sederajat_ibu $_{i t}+\beta_{5}$ Perguruan tinggi_ibu ${ }_{i t}+$ $\beta_{6}$ Lainnya_ibu $_{i t}+\beta_{7} S D$ sederajat_ayah ${ }_{i t}+\beta_{8} S M P$ sederajat_ayah $_{i t}+\beta_{9} S M A$ sederajat_ayah ${ }_{i t}+$ $\beta_{10}$ Perguruan tinggi_ayah ${ }_{i t}+\beta_{11}$ lainnya_ayah ${ }_{i t}+$ $\beta_{12}$ child_sex $_{i}+\beta_{13}$ child_age $_{i t}+$ $\beta_{14}$ child_yearsofschool ${ }_{i t}{ } \quad \beta_{15}$ hh_size $_{i t}+$ $\beta_{16}$ expend_month $h_{i t}+\beta_{17}$ educ_exp ${ }_{i t}+\beta_{18}$ residence $_{i t}+\varepsilon_{i t}$

\section{HASIL DAN PEMBAHASAN}

\section{Status Migrasi Orang tua}

Transisi perubahan status migrasi orang tua pada dua periode survei ditunjukkan pada Gambar 2. Status migrasi orang tua dibedakan menjadi orang tua yang migrasi dan tidak migrasi. Orang tua yang migrasi dalam penelitian ini artinya mereka yang pernah migrasi dalam rentang waktu tahun 2000-2007 pada survei IFLS 4 dan atau rentang waktu 2007-2014 pada survei IFLS 5. Dari hasil pengolahan ditemukan bahwa terdapat $13,2 \%$ anak memiliki orang tua yang tidak migrasi atau non-migran pada survei tahun 2007 namun memiliki riwayat migrasi atau menjadi migran pada survei tahun 2014. Sementara itu transisi dari orang tua yang memiliki riwayat migrasi pada tahun 2007 menjadi tidak migrasi pada tahun 2014 adalah 72,4\%. Sebagian besar orang tua yang memiliki riwayat migrasi pada tahun 2014 juga memiliki riwayat migrasi pada periode sebelumnya (IFLS 4).
Gambar 2. Transisi Status Migrasi Orang tua, 2007 dan 2014

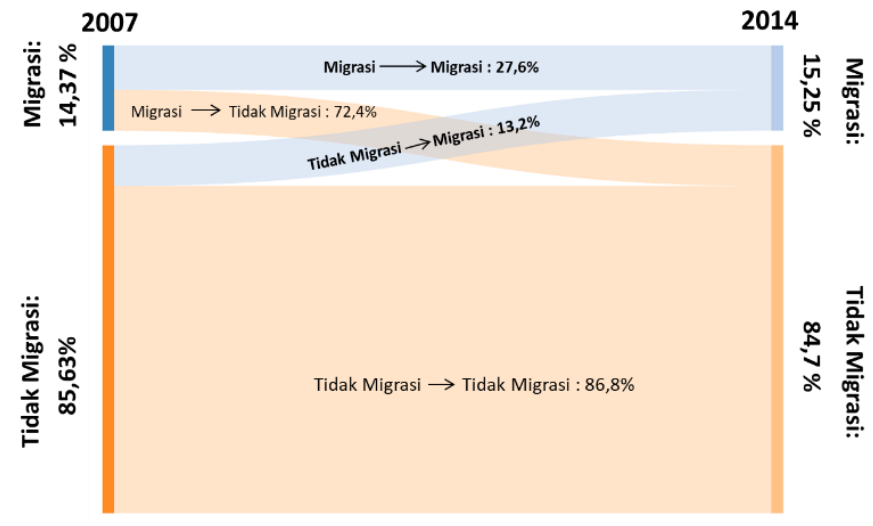

Sumber: IFLS 4 dan IFLS 5, telah diolah kembali

Selain menggunakan z-skor $=0$ untuk mengategorikan standar atau benchmark untuk mengetahui berapa proporsi anak yang memiliki skor di atas dan di bawah rata-rata, maka perlu juga menganalisis rata-rata dan nilai median skor kognitif per level pertanyaan sebagai benchmark. Hal ini untuk lebih mengetahui secara spesifik distribusi sampel berdasarkan rata-rata skor kognitif dan nilai median per kategori umur atau level tes kognitif. Skor kognitif dijadikan kategori hanya dalam analisis deskriptif agar memudahkan menganalisis dan menginterpretasi nilai z-skor pada sampel penelitian.

\section{Skor Kognitif Anak Menurut Status Migrasi Orang tua}

Skor kognitif dalam penelitian ini menggunakan cut-off berdasarkan nilai rata-rata dan nilai median yang dibagi menjadi dua kategori yaitu di atas rata-rata dan di bawah rata-rata dan di atas median dan di bawah median. Cut-off poin dibedakan berdasarkan level tes kognitif. Cut-off Level 1 adalah 0,241 untuk rata-rata dan 0,134 untuk median sedangkan cut-off Level 2 adalah 0,0013 untuk rata-rata dan $-0,0032$ untuk median.

Jika menggunakan nilai rata-rata sebagai benchmark, persentase kelompok anak dari orang tua migran maupun non-migran lebih banyak yang memiliki skor di atas rata-rata baik tahun 2007 maupun tahun 2014 sebagaimana deskripsi keseluruhan sampel yang telah disebutkan sebelumnya. Namun jika membandingkan 
proporsi skor kognitif pada kategori di atas rata-rata, tahun 2014 proporsi anak migran lebih besar dibandingkan anak non-migran meskipun perbedaannya tidak terlalu signifikan. Sementara itu, pada tahun 2007 persentase anak non-migran yang berada di atas rata-rata lebih besar dibandingkan anak migran (Gambar 3).

Gambar 3. Skor Kognitif berdasarkan Status Migrasi Orang tua dengan Benchmark Rata-rata, 2007 dan 2014

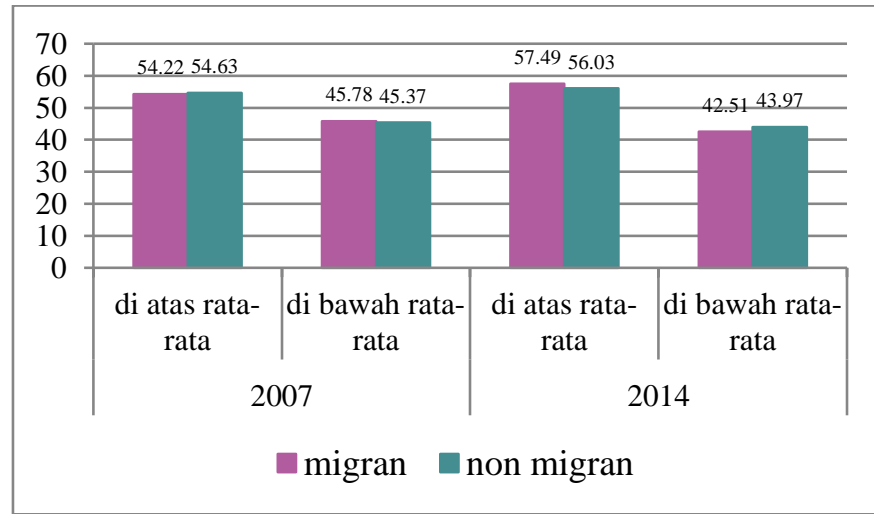

Sumber: IFLS 4 dan IFLS 5, telah diolah kembali

Gambar 4 menjelaskan distribusi persentase skor kognitif anak berdasarkan status migrasi orang tua dengan menggunakan benchmark nilai median. Pada tahun 2007 persentase anak migran maupun nonmigran lebih banyak yang berada di atas median akan tetapi pada tahun 2014 lebih banyak persentase yang berada di bawah median. Anak migran pada tahun 2014 yang berada di atas median memiliki proporsi lebih besar dibandingkan proporsi anak non-migran yang berada di atas median.

Gambar 4. Skor Kognitif berdasarkan Status Migrasi Orang tua dengan Benchmark Median, 2007 dan 2014

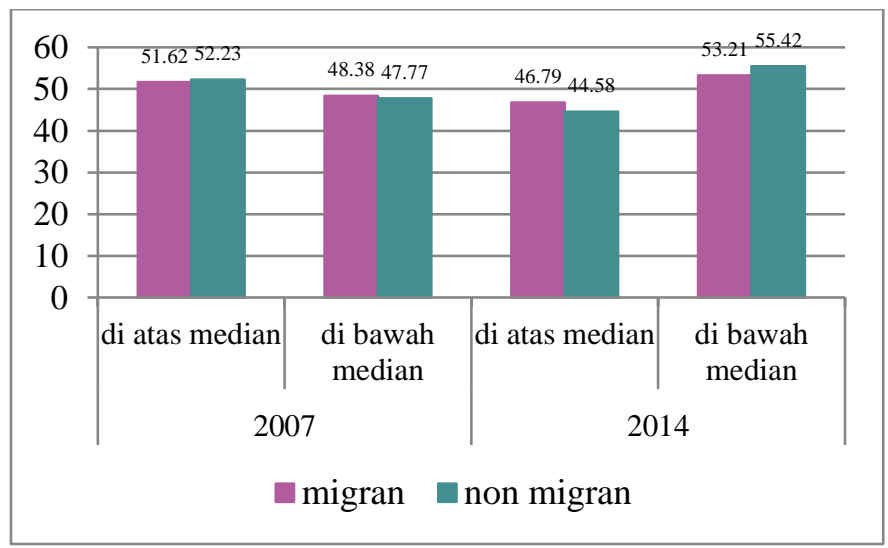

Sumber: IFLS 4 dan IFLS 5, telah diolah kembali
Analisis berikutnya adalah uji beda rata-rata dengan menggunakan independent $t$ test untuk mengetahui perbedaan skor kognitif dan karakteristik lainnya antara dua kelompok yaitu kelompok anak dari orang tua migran atau rumah tangga migran dengan anak dari orang tua non-migran atau rumah tangga non-migran baik pada IFLS 4 maupun IFLS 5. Hasil independent $t$ test tersebut disajikan pada Tabel 2.

Berdasarkan Tabel 2, diketahui bahwa rata-rata skor kognitif anak migran lebih rendah dibandingkan kelompok anak non-migran dengan perbedaan rata-rata sebesar -0,02250. Meskipun demikian, $p$ value $>0,05$ atau tidak signifikan secara statistik. Dapat disimpulkan bahwa tidak ada perbedaan rata-rata skor kognitif antara kelompok anak migran dengan anak non-migran.

Selanjutnya, berdasarkan karakteristik orang tua yaitu pendidikan ayah dan pendidikan ibu menunjukkan pola yang sama, di mana $p$-value signifikan pada semua kategori kecuali pada kategori pendidikan SMP sederajat. Ini berarti rata-rata pendidikan terakhir yang ditamatkan ayah atau ibu dari anak migran berbeda atau tidak seragam dengan rata-rata pendidikan terakhir yang ditamatkan oleh ayah atau ibu dari anak nonmigran. Rata-rata kelompok anak migran lebih tinggi pada kategori pendidikan ayah dan ibu tingkat SMA dan perguruan tinggi dibandingkan kelompok anak non-migran. Hasil deskriptif menunjukkan bahwa mayoritas orang tua migran memiliki tingkat pendidikan yang lebih baik dibandingkan orang tua non-migran. Orang tua migran paling banyak berpendidikan tingkat SMA dan sederajat sementara orang tua non-migran mayoritas memiliki pendidikan tingkat SD dan sederajat. Namun hal ini tidak berkontribusi meningkatkan skor kognitif anak migran karena koefisien regresi status migrasi orang tua pada Model 1 bernilai negatif. 
Tabel 2. Hasil Independent t test Perbedaan Skor Kognitif dan Variabel Kontrol Lainnya antara Anak dari Orang tua Migran dan Anak dari Orang tua Non-Migran Tahun 2007 dan 2014

\begin{tabular}{|c|c|c|c|c|}
\hline \multirow{2}{*}{ Variabel } & \multicolumn{3}{|c|}{ Rerata } & \multirow[b]{2}{*}{$\begin{array}{r}\text { Perbedaan } \\
\text { Rerata }\end{array}$} \\
\hline & Migran & $\begin{array}{r}\text { Non- } \\
\text { migran }\end{array}$ & $\begin{array}{r}P> \\
|\mathbf{t}|\end{array}$ & \\
\hline Z-Skor Kognitif Anak & $-0,0201$ & 0,0024 & 0,599 & $-0,02250$ \\
\hline \multicolumn{5}{|l|}{ Jenis Kelamin Anak } \\
\hline Laki-Laki & 0,50 & 0,54 & 0,049 & $-0,042$ \\
\hline Perempuan (ref) & 0,50 & 0,46 & 0,049 & 0.042 \\
\hline Umur (tahun) & 14,01 & 14,46 & 0,034 & $-0,449$ \\
\hline Lama Sekolah Anak (tahun) & 6,72 & 6,95 & 0,201 & $-0,233$ \\
\hline \multicolumn{5}{|l|}{ Pendidikan Ayah } \\
\hline SD sederajat & 0,28 & 0,43 & 0,000 & $-0,158$ \\
\hline SMP sederajat & 0,19 & 0,16 & 0,052 & 0,033 \\
\hline SMA sederajat & 0,36 & 0,26 & 0,000 & 0,106 \\
\hline Perguruan Tinggi & 0,15 & 0,10 & 0,000 & 0,053 \\
\hline lainnya & 0,00 & 0,01 & 0,000 & $-0,010$ \\
\hline tidak/belum sekolah (ref) & 0,01 & 0,04 & 0,000 & $-0,024$ \\
\hline \multicolumn{5}{|l|}{ Pendidikan Ibu } \\
\hline SD sederajat & 0,33 & 0,48 & 0,000 & $-0,151$ \\
\hline SMP sederajat & 0,20 & 0,20 & 0,753 & $-0,005$ \\
\hline SMA sederajat & 0,34 & 0,20 & 0,000 & 0,139 \\
\hline Perguruan Tinggi & 0,09 & 0,05 & 0,001 & 0,04 \\
\hline lainnya & 0,00 & 0,00 & 0,000 & $-0,004$ \\
\hline tidak/belum sekolah (ref) & 0,04 & 0,06 & 0,044 & $-0,018$ \\
\hline & $771.031,7$ & & & \\
\hline Pengeluaran Rumah Tangga Per kapita & 5 & $817.576,33$ & 0,521 & $-46.544,59$ \\
\hline & $468.216,1$ & & & \\
\hline Pengeluaran Pendidikan Per Kapita & 8 & $523.521,03$ & 0,104 & $-55.304,85$ \\
\hline Jumlah Anggota Rumah Tangga & 6,73 & 7,04 & 0,022 & $-0,304$ \\
\hline \multicolumn{5}{|l|}{ Wilayah Tempat Tinggal } \\
\hline Perkotaan & 0,65 & 0,43 & 0,000 & 0,080 \\
\hline Perdesaan (ref) & 0,35 & 0,43 & 0,000 & $-0,080$ \\
\hline Kepemilikan Lahan & 0,23 & 0,31 & 0,000 & 0,085 \\
\hline Total observasi (n) & 635 & 3.653 & 4.288 & 4.288 \\
\hline
\end{tabular}

Keterangan: $\mathrm{SD}=$ sekolah dasar, $\mathrm{SMP}=$ sekolah menengah pertama, $\mathrm{SMA}=$ sekolah menengah atas

(Ref) : reference category

Sumber: IFLS 4 dan IFLS 5, telah diolah kembali

Berdasarkan jumlah anggota rumah tangga menunjukkan adanya perbedaan di mana kelompok anak migran memiliki rata-rata jumlah anggota rumah tangga yang lebih sedikit dibandingkan anggota rumah tangga dari anak non-migran. Selanjutnya karakteristik wilayah tempat tinggal juga menunjukkan ada perbedaan antara dua kelompok tersebut dan sangat signifikan. Rata-rata anak migran yang tinggal di perkotaan lebih besar dibandingkan anak dari nonmigran. Perbedaan rata-rata antara kedua kelompok adalah sebesar 0,080. Kelompok anak non-migran juga mayoritas tinggal di perkotaan namun perbandingan proporsi anak migran yang tinggal di perkotaan lebih besar dari yang tinggal di perdesaan.

Kesimpulan yang dapat diambil dari hasil uji ini adalah tidak terdapat perbedaan skor kognitif antara anak dari orang tua migran dengan orang tua non-migran. Meskipun terlihat ada perbedaan rata-rata, namun tidak signifikan secara statistik. Secara keseluruhan, anak dari keluarga migran memiliki beberapa perbedaan karakteristik dengan anak dari keluarga non-migran. Karakteristik tersebut diantaranya karakteristik demografi, karakteristik sosial dan ekonomi, dan karakteristik wilayah tempat tinggal.

Analisis inferensial dalam penelitian ini digunakan untuk melihat pengaruh migrasi orang tua dan variabelvariabel kontrol lainnya terhadap kognitif anak. Model 1 dianalisis menggunakan regresi pooled least square serta two-stage least square dengan menggunakan instrumental variabel. Pengaruh migrasi orang tua 
terhadap kognitif anak pada Model 1 tidak lebih kuat dibandingkan karakteristik-karakteristik lainnya, seperti pendidikan ibu dan lama sekolah anak. Temuan pada Model 1 sejalan dengan beberapa penelitian sebelumnya yang juga menemukan bahwa migrasi orang tua memiliki pengaruh yang signifikan negatif pada skor kemampuan kognitif anak (Jampaklay, Richter, \& Tangchonlatip, 2018; Nguyen, 2016; Powers, 2011; Remeijers, 2016; Xu, Xu, Simpkins, \& Warschauer, 2019; Zhang, Behrman, Fan, Wei, \& Zhang, 2014).
Penelitian-penelitian tersebut menitikberatkan pada anak yang ditinggalkan karena migrasi orang tua. Sebagaimana telah disampaikan pada bagian tinjauan literatur bahwa ketidakberadaan orang tua akibat migrasi dapat memengaruhi perkembangan kognitif anak, diantaranya melalui mekanisme kurangnya input orang tua dan biaya psikologis karena terpisah dari orang tua terutama untuk anak yang berusia lebih muda. Input orang tua dalam hal ini dapat berupa waktu yang dialokasikan untuk investasi modal manusia pada anak atau untuk hal-hal yang berkenaan dengan pencapaian pendidikan yang juga melibatkan kemampuan kognitif misalnya seperti after-school tutoring.

Tabel 3.Hasil Regresi Pooled Least Square dan Instrumental Variable 2SLS Tahun 2007 dan 2014

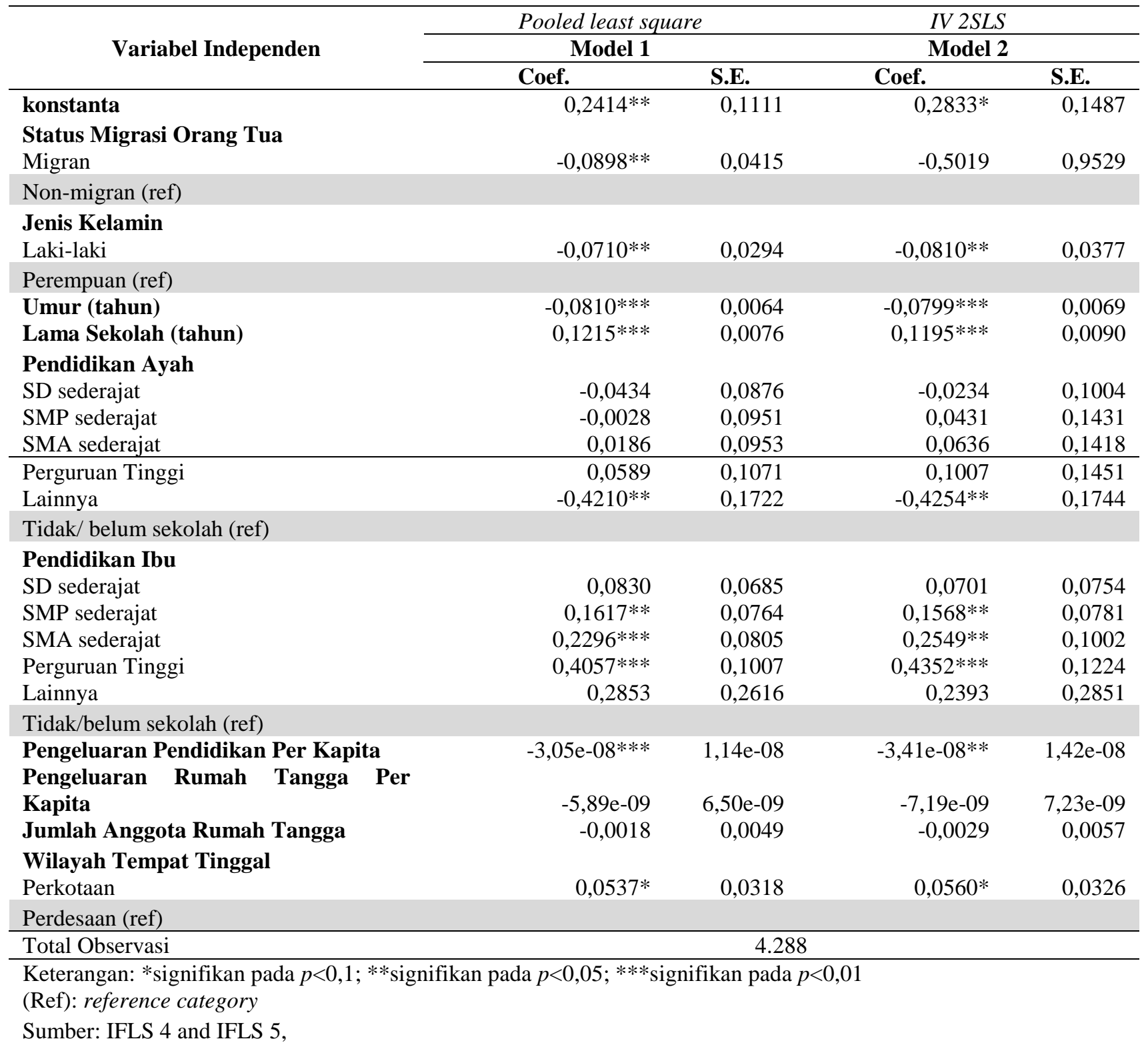


Dari beberapa studi sebelumnya dapat disimpulkan bahwa migrasi orang tua dapat memiliki pengaruh negatif terhadap perkembangan modal manusia pada anak terutama disebabkan oleh kurangnya input orang tua dalam hal pengasuhan, pengawasan, dan monitoring. Sebagaimana yang disebutkan oleh Parrenas (2005) bahwa migrasi orang tua menimbulkan biaya sosial yaitu kurangnya figur otoritas, kurangnya dukungan, dan kurangnya pengawasan yang fundamental bagi perkembangan anak dan capaian pendidikan.

Namun hasil pada Model 1 dihadapkan dengan permasalahan endogenitas yang sering ditemui dalam studi migrasi. Jika keputusan migrasi orang tua berkorelasi dengan error term atau karakteristik yang tidak teramati atau bila orang tua bermigrasi untuk meningkatkan kemampuan kognitif anak misalnya dengan mengakses pendidikan yang lebih baik dan berkualitas di tempat tujuan, maka kemungkinan terjadi endogenitas (variabel migrasi orang tua endogen). Migran adalah sekelompok individu yang sangat terpilih (highly selected) (Wisana, 2012). Keputusan orang tua untuk bermigrasi memungkinkan berkorelasi dengan error term di mana ada kemungkinan karakteristik yang tidak teramati yang menjelaskan migrasi juga berkorelasi dengan kognitif anak. Oleh karena itu, estimasi menggunakan pooled least square maupun OLS cenderung bias dan tidak konsisten. Untuk mengatasi permasalahan tersebut maka dalam penelitian ini digunakan variabel instrumen dengan dua-tahap regresi (2SLS) untuk memisahkan atau mengisolasi bagian yang tidak berkorelasi dengan error. Hal ini karena regresi IV $2 S L S$ memecah $\mathrm{X}$ menjadi dua bagian: yaitu bagian yang mungkin berkorelasi dengan error dan bagian yang tidak berkorelasi. Sehingga dapat digunakan untuk estimasi beta 1 dan untuk mendapatkan estimasi yang konsisten seperti pada Model 2.

Setelah melakukan koreksi dengan memasukkan variabel instrumen kepemilikan lahan yang diestimasi dengan two-step least square seperti yang terlihat pada Model 2, maka dapat diketahui bahwa migrasi orang tua berubah menjadi tidak signifikan secara statistik dalam memengaruhi kognitif anak. Bila dilakukan analisis terpisah berdasarkan tahun juga menunjukkan tidak terdapat pengaruh signifikan antara variabel utama dan variabel dependen. Sementara itu variabel kontrol lainnya menunjukkan arah dan pengaruh yang hampir sama pada semua model.

Pada Model 2 dapat disimpulkan bahwa migrasi orang tua tidak memiliki pengaruh terhadap kognitif anak. Arah koefisien regresi tetap negatif namun tidak signifikan secara statistik. Terdapat beberapa alasan yang diduga menjadi penyebab mengapa pada penelitian ini ditemukan tidak terdapat pengaruh signifikan migrasi orang tua terhadap skor kognitif anak. Yang pertama adalah karena definisi migrasi dalam penelitian ini mencakup anak yang ikut migrasi bersama orang tua maupun anak yang ditinggalkan. Studi-studi sebelumnya juga menyebutkan bahwa hubungan antara migrasi orang tua dan output modal manusia atau perkembangan anak masih belum jelas. Sebagian besar menunjukkan arah positif melalui adanya efek remitansi dan peningkatan pendapatan. Akan tetapi dalam penelitian ini tampaknya efek positif remitansi belum dapat meningkatkan investasi modal manusia pada anak. Terlihat pada Tabel 2, rata-rata pengeluaran pendidikan per kapita rumah tangga dan pengeluaran per kapita rumah tangga secara keseluruhan pada rumah tangga migran lebih kecil dibandingkan rumah tangga non-migran.

Gambar 5. Status Migrasi Orang tua berdasarkan Kuintil Pengeluaran Rumah Tangga, 2007 dan 2014

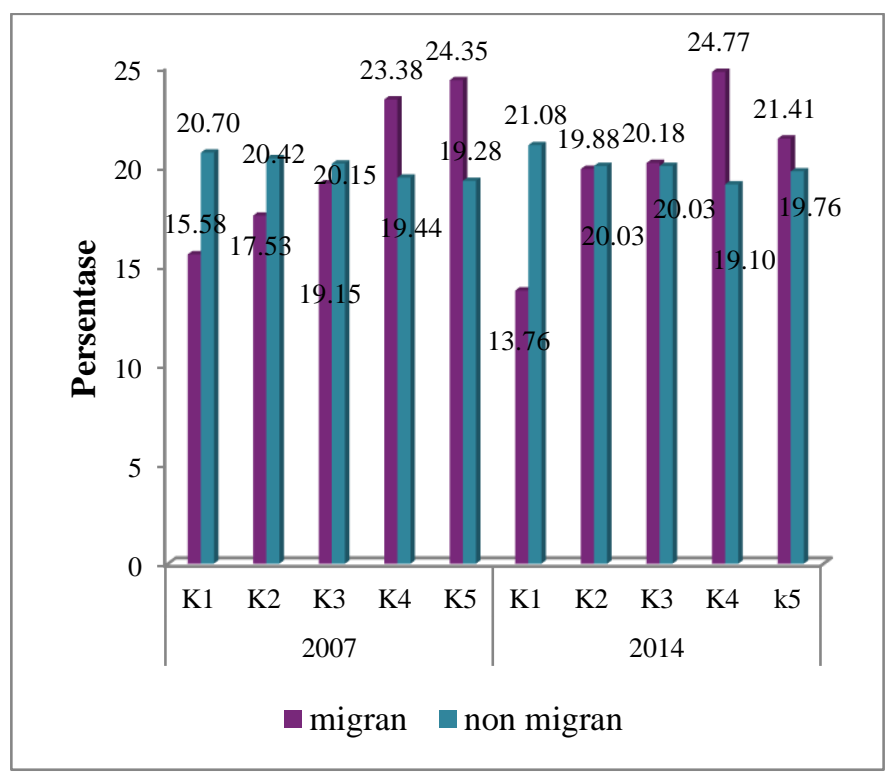

Source: IFLS 4 dan IFLS 5, telah diolah kembali 
Gambar 5 menunjukkan bahwa meskipun secara ratarata pengeluaran rumah tangga anak dari orang tua migran lebih rendah dibandingkan anak non-migran, namun berdasarkan kuintil pengeluaran rumah tangga menunjukkan bahwa persentase rumah tangga migran pada kuintil 1 (K1) tahun 2007 mengalami penurunan pada tahun 2014. Sementara itu rumah tangga migran pada kuintil 2 (K2) mengalami peningkatan pada tahun 2014, kuintil 3 (K3) juga mengalami peningkatan namun tidak terlalu signifikan. Persentase rumah tangga migran yang berada pada kuintil 4 (K4) juga meningkat dengan peningkatan yang lebih besar dibandingkan pada kuintil lain. Persentase rumah tangga migran yang berada pada kuintil 5 (K5) mengalami penurunan pada tahun 2014. Sementara perubahan pada rumah tangga non-migran cenderung stabil pada setiap kuintil.

Kemudian, dampak migrasi pada informasi dan persepsi orang tua terhadap investasi modal manusia pada anak dan new parenting style dari daerah tujuan sepertinya tidak begitu berperan atau tidak terlihat. Orang tua yang bermigrasi berpotensi terpapar informasi yang lebih luas dari daerah tujuan yang dapat mengubah sikap, persepsi atau keyakinan mengenai pengembalian investasi modal manusia pada anak (Lee \& Park, 2010). Jika orang tua mendapatkan informasi mengenai pengembalian modal manusia yang positif di daerah tujuan maka dapat mendorong orang tua untuk mengalokasikan lebih dan berinvestasi pada peningkatan modal pada anaknya, karena orang tua dapat belajar lebih banyak tentang pentingnya investasi pada modal manusia. Namun pada penelitian ini hasil deskriptif menunjukkan rata-rata pengeluaran pendidikan anak dari orang tua migran lebih rendah dibandingkan non-migran.

Selanjutnya, hasil yang menunjukkan migrasi orang tua tidak memiliki pengaruh signifikan dalam penelitian ini diduga karena ada faktor-faktor lain yang lebih besar dalam memengaruhi kemampuan kognitif anak. Beberapa literatur mengungkapkan bahwa pembentukan modal manusia termasuk kemampuan kognitif lebih cenderung dibangun pada masa-masa awal kehidupan dan bergantung pada level awal modal manusia serta investasi yang dilakukan oleh orang tua (Attanasio, 2015; Cameron, 1993; Cunha \& Heckman, 2008). Hal serupa juga kemukakan oleh Adioetomo
(2018) di Indonesia bahwa seribu hari pertama atau tiga tahun pertama kehidupan termasuk sejak dalam kandungan merupakan masa yang paling kritis untuk pembentukan kemampuan kognitif anak yang akan terbawa sampai dewasa, usia kerja, dan bahkan sampai lanjut usia. Kecukupan gizi dan nutrisi sejak janin berada dalam kandungan dan bayi pasca lahir sangat penting karena periode ini merupakan dasar terbentuknya modal manusia yang akan menentukan tinggi rendahnya kualitas modal manusia (Adioetomo, 2018; Jukes dkk., 2002).

Oleh karena itu, intervensi pada saat anak berusia 7 tahun ke atas, yang menjadi sampel dalam penelitian ini, tidak memberikan pengaruh yang signifikan bagi perkembangan kognitif anak. Intervensi dari segi input keluarga seperti ketidakhadiran orang tua, adanya perubahan lingkungan dan tempat tinggal (jika anak ikut bermigrasi) akibat migrasi orang tua diduga tidak lagi begitu memengaruhi terutama pada responden yang berusia 15 tahun ke atas. Hal ini dapat menjelaskan temuan mengapa pada penelitian ini tidak terdapat pengaruh yang signifikan antara migrasi orang tua dan kognitif anak.

\section{Pengaruh Variabel Kontrol atau Karakteristik Lainnya terhadap Kognitif Anak}

Pada Model 2 karakteristik lain yang berpengaruh pada kognitif anak adalah jenis kelamin anak, umur anak, lama sekolah anak, pendidikan ibu, pengeluaran pendidikan per kapita, dan wilayah tempat tinggal. Sedangkan karakteristik pengeluaran rumah tangga dan jumlah anggota rumah tangga tidak memiliki pengaruh signifikan.

Variabel jenis kelamin memiliki pengaruh yang signifikan secara statistik terhadap skor kognitif anak. Anak laki-laki signifikan memengaruhi skor kognitif pada $\alpha=0,05$ dengan arah koefisien negatif sebesar 0,0710 . Artinya terdapat perbedaan skor kognitif antara anak laki-laki dan perempuan di mana anak laki-laki menurunkan skor kognitif sebesar 0,0810. Hasil ini didukung dengan temuan hasil deskriptif di mana ratarata skor kognitif anak laki-laki lebih kecil dibandingkan rata-rata anak perempuan. Lynn dan Kanazawa (2011) mengemukakan bahwa pada usia sebelum pubertas (7-11 tahun) kemampuan kognitif 
anak perempuan lebih unggul dibandingkan anak lakilaki namun setelah usia pubertas ( $>16$ tahun) anak lakilaki memiliki skor kognitif yang lebih tinggi.

Berdasarkan umur anak, dapat disimpulkan pada Tabel 3, bahwa kenaikan satu tahun umur anak menurunkan skor kognitif sebesar 0,0799 dengan signifikansi pada $\alpha=0,01$. Temuan ini bertentangan dengan teori dan studi sebelumnya di mana seharusnya skor kognitif diekspektasi meningkat seiring bertambahnya umur (Maika dkk., 2013). Dalam penelitian ini diduga penurunan skor kognitif pada usia yang lebih tua (yang menjawab skor kognitif Level 2) terutama karena sebagian besar kelompok usia di atas 15 tahun memiliki skor di bawah median dan rata-rata skor kognitif yang lebih kecil dibandingkan kelompok usia yang menjawab pertanyaan kognitif Level 1 . Standar deviasi skor kognitif pada tahun 2014 juga lebih besar dibandingkan tahun 2007 yang menunjukkan sebaran pada tahun 2014 lebih bervariasi. Hal ini mengindikasikan bahwa pembelajaran di sekolah tidak terlalu berkontribusi pada hasil tes kognitif.

Lama sekolah anak berpengaruh signifikan positif terhadap kognitif anak di mana peningkatan satu tahun lama sekolah meningkatkan skor kognitif sebesar 0,1195 . Hubungan antara lamanya durasi pendidikan dengan perkembangan kognitif masih belum jelas dan menjadi fokus para peneliti sebelumnya. Hasil penelitian ini sejalan dengan penelitian yang dilakukan oleh Ceci (1991) serta Cahan dan Cohen (1989) yang menunjukkan bahwa responden yang memiliki durasi pendidikan yang lebih panjang memiliki skor IQ yang lebih tinggi dibandingkan yang durasi pendidikannya lebih pendek.

Karakteristik orang tua yang berpengaruh signifikan adalah pendidikan ibu. Pendidikan ibu memiliki peran yang sangat penting dalam memprediksi skor kognitif anak terlihat dari signifikansi dan pengaruh yang lebih besar dibandingkan variabel lainnya dan variabel utama. Hampir semua kategori pendidikan ibu signifikan secara statistik dan berpengaruh positif terhadap skor kognitif anak kecuali pendidikan SD sederajat dan Lainnya. Ibu yang memiliki pendidikan terakhir SMP sederajat signifikan meningkatkan skor kognitif sebesar 0,1568. Kemudian, Ibu yang memiliki pendidikan terakhir SMA sederajat signifikan meningkatkan skor kognitif sebesar 0,2549 dan ibu yang memiliki pendidikan terakhir setingkat Perguruan Tinggi signifikan meningkatkan skor kognitif anak sebesar 0,4352. Dari hasil tersebut dapat diketahui bahwa semakin tinggi pendidikan ibu maka semakin besar pengaruhnya dalam meningkatkan skor kognitif anak. Temuan ini telah banyak diteliti diantaranya penelitian yang dilakukan oleh Magnuson (2007) dan Reardon (2011) yang menunjukkan bahwa peningkatan pendidikan ibu berhubungan dengan peningkatan skor kognitif anak.

Selanjutnya, berdasarkan karakteristik rumah tangga yaitu pengeluaran pendidikan menunjukkan bahwa terdapat pengaruh signifikan negatif. Peningkatan satu rupiah pengeluaran pendidikan menurunkan skor kognitif anak sebesar 3,05e-08. Gambar 6 menunjukkan bahwa pada tahun 2007, semakin tinggi kuintil pengeluaran pendidikan maka distribusi persentase responden yang memiliki skor di atas ratarata juga meningkat.

Sebaliknya responden yang memiliki skor di bawah rata-rata terdistribusi paling banyak pada kuintil 1 dan 2 atau pada kelompok pengeluaran pendidikan $20 \%$ terbawah. Pola yang sama juga terjadi pada tahun 2014. Pengeluaran pendidikan dalam penelitian ini berpengaruh negatif terhadap skor kognitif. Hal ini diduga kaitannya dengan kualitas pendidikan di mana biaya pendidikan yang lebih besar tidak selalu berbanding lurus dengan kualitas yang ditunjukkan dengan nilai skor kognitif anak. Dalam rentang tujuh tahun, penulis tidak memiliki informasi atas perubahan kondisi sosial anak seperti kemampuan anak itu sendiri (innate ability) maupun kualitas pendidikan sebagai input sekolah anak. Terdapat kemungkinan di mana biaya pendidikan yang tinggi tidak sejalan dengan kualitas pendidikan. Selain itu biaya pendidikan pada penelitian ini mencakup biaya total terkait pendidikan yaitu biaya sumbangan pengembangan pendidikan (SPP), biaya transportasi, biaya kursus, akomodasi dan sebagainya sehingga pengeluaran pendidikan terdiri dari berbagai aspek. 
Gambar 6. Skor Kognitif berdasarkan Kuintil Pengeluaran Pendidikan Per Kapita, 2007 dan 2014

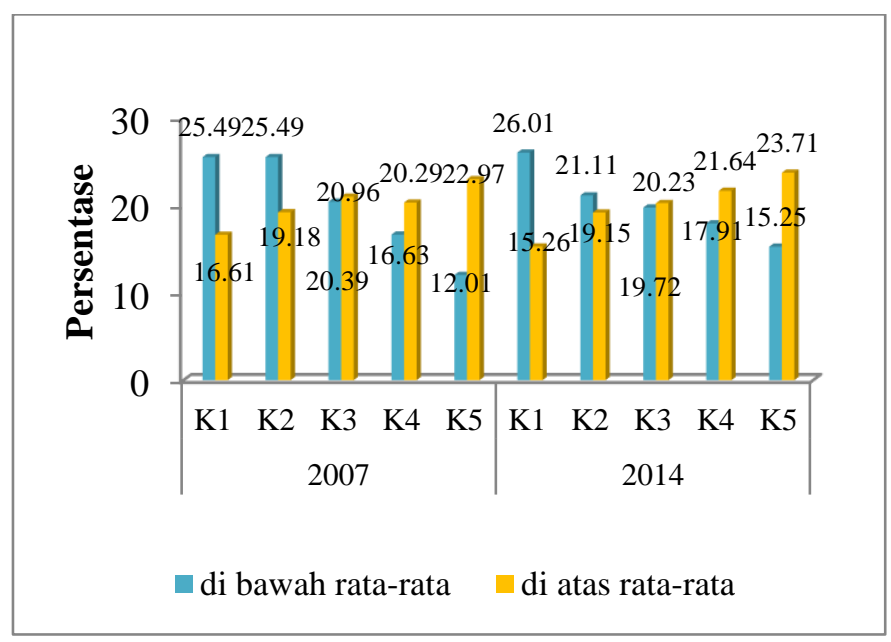

Source: IFLS 4 dan IFLS 5, telah diolah kembali

Kemudian, berdasarkan wilayah tempat tinggal, anak yang tinggal di wilayah perkotaan meningkatkan skor kognitif sebesar 0,0560 pada tingkat signifikansi $\alpha=$ 0,10 . Terjadi peningkatan jumlah anak yang tinggal di perkotaan dalam kurun waktu 7 tahun di IFLS 5 (2014), hal ini diduga menjadi penyebab variabel wilayah tempat tinggal memiliki pengaruh terhadap skor kognitif anak. Hasil ini juga didukung hasil deskriptif yang menunjukkan bahwa terdapat perbedaan rata-rata skor kognitif di mana anak di perkotaan memiliki skor kognitif di atas rata-rata sementara anak di perdesaan sebagian besar memiliki skor kognitif di bawah ratarata. Hal ini juga diduga karena terdapat perbedaan sosial ekonomi antara anak yang tinggal di perkotaan dengan yang tinggal di perdesaan.

\section{KESIMPULAN DAN SARAN}

Hasil uji beda rata-rata sampel saling bebas menunjukkan bahwa tidak terdapat perbedaan skor kognitif antara kelompok anak migran dengan anak non-migran. Terdapat beberapa karakteristik yang menunjukkan ada perbedaan signifikan antara kelompok anak dari orang tua migran dengan anak dari orang tua non-migran. Diantaranya jenis kelamin, umur anak, pendidikan ayah, pendidikan ibu, karakteristik rumah tangga seperti jumlah anggota rumah tangga, dan wilayah tempat tinggal.
Hasil penelitian ini dapat memberikan gambaran bahwa di Indonesia, dengan menggunakan tes penilaian kognitif pada survei IFLS, pengaruh migrasi orang tua tidak signifikan secara statistik terhadap kognitif anak. Sementara itu, kognitif anak dipengaruhi oleh variabelvariabel independen lainnya, seperti jenis kelamin dan umur anak yang secara signifikan negatif memengaruhi skor kognitif, lama sekolah signifikan meningkatkan skor kognitif anak. Semakin tinggi pendidikan ibu maka semakin besar pengaruhnya dalam meningkatkan skor kognitif anak. Pengeluaran pendidikan per kapita menunjukkan pengaruh signifikan negatif terhadap kognitif anak dan tinggal di wilayah perkotaan terbukti signifikan meningkatkan skor kognitif anak.

Berdasarkan hasil penelitian ini, dapat disimpulkan bahwa perkembangan kognitif anak tidak dipengaruhi oleh migrasi orang tua. Dengan kata lain, terlepas dari anak berasal dari rumah tangga migran atau pernah memiliki riwayat migrasi, baik itu yang ikut migrasi bersama orang tua dan seluruh anggota keluarga maupun yang ditinggalkan oleh orang tua, tidak terdapat perbedaan signifikan dalam hal performa kualitas modal manusia yang diukur dengan skor kognitif. Dalam penelitian ini beberapa mekanisme yang umumnya menghubungkan migrasi orang tua dan pencapaian kualitas modal manusia khususnya kemampuan kognitif anak tidak begitu berperan. Selain itu, diduga karena ada faktor-faktor lain yang lebih besar dalam memengaruhi kemampuan kognitif anak seperti pendidikan ibu, lama sekolah, dan kemampuan bawaan (innate ability). Oleh karena itu, implikasi kebijakan terkait dengan peningkatan kualitas modal manusia adalah dengan memfokuskan perhatian dan intervensi pada periode awal kehidupan atau seribu hari pertama kehidupan. Selain itu, perlunya meningkatkan akses pendidikan pada perempuan mengingat pendidikan ibu berkontribusi cukup besar dalam meningkatkan kognitif anak. Ibu yang berpendidikan dapat mendorong kecukupan gizi dan nutrisi sejak janin dalam kandungan sehingga dapat berkontribusi pada tinggi rendahnya kualitas modal manusia pada anak.

Keterbatasan pada penelitian ini diantaranya adalah dari segi identifikasi orang tua migran atau rumah tangga migran. Penelitian ini belum memisahkan antara anak yang ditinggalkan oleh orang tua dengan yang ikut migrasi bersama seluruh anggota keluarga. Selain itu 
dalam penelitian ini migrasi belum dipisahkan berdasarkan jarak atau tempat tujuan apakah migrasi desa-kota atau migrasi antar provinsi atau regional. Status migrasi orang tua yang digunakan adalah pada dua periode survei dan bersifat panel. Individu yang memiliki orang tua migran pada tahun 2007 namun menjadi tidak migrasi pada 2014 tetap diidentifikasi sebagai individu yang memiliki orang tua migran ataupun sebaliknya. Sehingga kemungkinan ada kecenderungan terjadi bias dalam variabel migrasi orang tua.

Untuk penelitian selanjutnya, disarankan untuk memisahkan antara variabel anak yang ditinggalkan oleh orang tua dan variabel anak yang dibawa bermigrasi bersama keluarga untuk dapat lebih spesifik dalam menganalisis melalui jalur manakah migrasi memengaruhi performa kognitif anak karena memiliki kondisi yang berbeda. Kemudian, penelitian selanjutnya perlu lebih spesifik dalam menganalisis tipe migrasi orang tua (internal atau internasional). Instrumental variable (IV) lain untuk keputusan migrasi juga perlu dimasukkan, seperti kepemilikan rumah atau aset, migration network, labor market shocks, upah, dan jumlah anak yang berusia di bawah enam tahun. Selain itu, disarankan juga untuk memasukkan variabel-variabel terkait seperti berat lahir, keberadaan saudara kandung, pengasuhan (care giver), kemampuan kognitif orang tua untuk mengontrol adanya penurunan bakat antar generasi atau pengaruh secara genetika, dan kondisi antropometri anak.

\section{DAFTAR PUSTAKA}

Adams, R., \& Cuecuecha, A. (2010). The economic impact of international remittances on poverty and household consumption and investment in Indonesia. World Bank. https://doi.org/10.1596/1813-9450-5433

Adioetomo, S. M. (2018). Seribu hari pertama kehidupan: awal pembangunan keterampilan kognitif. Dalam S. M. Adioetomo \& E. L. Pardede (Editor), Memetik bonus demografi membangun manusia sejak dini (edisi ke-1, pp. 65-79). Rajawali Pers.

Antman, F. M. (2012). Gender, educational attainment, and the impact of parental migration on children left behind. Journal of Population Economics, 25(4), 1187-1214. https://doi.org/10.1007/s00148-012-0423-y

Attanasio, O. (2015). The determinants of human capital formation during the early years of life. Journal of the European Economic Association, 13(6), 949-997. https://doi.org/10.1111/jeea.12159

Becker, G. S. (1964). Human capital: A theoretical and emprical analysis, with special reference to education (edisi ke-3). National Bureau of Economic Research.

Berbée, P. P. L. (2007). What constitutes success in Pacific Island community conserved areas? [Tesis Magister, Lund University]. LUP Student Papers. http://lup.lub.lu.se/studentpapers/record/8917503

Cahan, S., \& Cohen, N. (1989). Age versus schooling effects on intellegence development. Child Development, 60(5), 1239-1249. https://doi.org/10.2307/1130797

Cameron, S. V. (1993). The nonequivalence of high school equivalents. Journal of Labor Economics, $\quad 11(1), \quad 1-47$. https://doi.org/10.1086/298316

Catrinescu, N., Wilis, J., MacAuslan, I., Barca, V., Sandu, V., \& Rimmer, M. (2011). Impact of labour migration on children left behind in Tajikistan. United Nations Children's Fund (UNICEF).

https://hdl.loc.gov/loc.gdc/gdcebookspublic.2 014363276

Ceci, S. J. (1991). How much does schooling influence general intelegence and its cognitive components? Reassesment of the evidence. Developmental Psychology, 27(5), 703-722. https://doi.org/10.1037/0012-1649.27.5.703

Cunha, F., \& Heckman, J. J. (2008). Formulating, identifying and estimating the technology of cognitive and noncognitive skill formation. Journal of Human Resources, 43(4), 738-782. https://doi.org/10.3368/jhr.43.4.738

Cuong, N. V., \& Linh, V. H. (2016). Should parents work away from or close to home? The effect of parental absence on children's time use in Vietnam. Journal of Human Development and Capabilities, 17(1), 110-124. https://doi.org/10.1080/19452829.2015.11037 11

Ferrone, L., \& Giannelli, G. C. (2015). Household 
migration and child educational attainment: The case of Uganda. IZA DP No. 8927. http://ftp.iza.org/dp8927.pdf

Gong, X., Kong, S. ., Li, S., \& Meng, X. (2008). China's dilemma, economic growth, the environment and climate change. Dalam L. Song, \& W. T. Woo (Editor), Rural-urban migrants: A driving force for growth. Asian Pasific Press and C. Brookings Institution Press.

Groppo, V., \& Mendola, M. (2014). The short-run costs of moving: internal migration and consumption growth in Indonesia. https://editorialexpress.com/cgibin/conference/download.cgi?db_name=ESPE 2014\&paper_id=595

Gujarati, D. N. (2003). Basic Econometrics (edisi ke4). McGraw-Hill Education.

Hanushek, E. A., \& Woessmann, L. (2008). The role of cognitive skills in economic development. Journal of Economic Literature, 46(3), 607668. https://doi.org/10.1257/jel.46.3.607

Heckman, J. J. (2007). The economics, technology, and neuroscience of human capability formation. Proceedings of the National Academy of Sciences, $104(33), \quad 13250$. https://doi.org/10.1073/pnas.0701362104

Hu, F. (2013). Does migration benefit the schooling of children left behind? Demographic Research, 29(2), 33-70. https://doi.org/10.4054/DemRes.2013.29.2

Hugo, G. (2002). Effects of international migration on the family in Indonesia. Asian and Pasific Migration Journal (APMJ), 11(1), 13-46. https://doi.org/10.1177/011719680201100102

Iqbal, S., Iqbal, F., \& Mozmi, R. A. (2014). Does male international migration effects the families left behind: Evidence from Gujrat Pakistan. Open Journal of Social Sciences, 2(2), 495-501. https://doi.org/10.4236/jss.2014.26058

Jampaklay, A., Richter, K., Tangchonlatip, K., \& Nanthamongkolchai, S. (2018). The impact of parental absence on early childhood development in the context of Thailand. Asian and Pacific Migration Journal, 27(2), 209-230. https://doi.org/10.1177/0117196818767439

Jukes, M., McGuire, J., Method, F., \& Sternberg, R.
(2002). Nutrition and education. In Nutrition: A foundation for development (pp. 1-4). United Nations Administrative Committee on Coordination/ Sub-Commitee on Nutrition (UN ACC/SCN).

Kandel, W., \& Kao, G. (2001). The impact of temporary labor migration on Mexican childrens educational aspirations performance. International Migration Review, 35(4), 12051231. https://doi.org/10.1111/j.17477379.2001.tb00058.x

Kholida, N. L. (2007). Analisis pengaruh migrasi terhadap pendidikan anak di Indonesia [Tesis Magister, Universitas Gadjah Mada]. Repository Perpustakaan UGM. http://etd.repository.ugm.ac.id/penelitian/detai $1 / 155231$

Lee, L., \& Park, A. (2010). Parental migration and child development in China. Gansu Survey of Children and Families Papers, 24. https://repository.upenn.edu/cgi/viewcontent.c gi?article $=1023 \&$ context=gansu_papers

Lee, M.-H. (2011). Migration and children's welfare in China: the schooling and health of children left behind. The Journal of Developing Areas, 44(2), $165-182$. https://doi.org/10.1353/jda.0.0104

Liu, Z., Yu, L., \& Zheng, X. (2018). No longer leftbehind: The impact of return migrant parents on children's performance. China Economic Review, 49, 184-196. https://doi.org/10.1016/j.chieco.2017.06.004

Lu, Y. (2014). Parental migration and education of leftbehind children: A comparison of two settings. Journal of Marriage and Family, 76(5), 10821098. https://doi.org/10.1111/jomf.12139

Lynn, R., \& Kanazawa, S. (2011). A longitudinal study of sex differences in intelligence at ages 7, 11 and 16 years. Personality and Individual Differences, 51(3), 321-324. https://doi.org/10.1016/j.paid.2011.02.028

Magnuson, K. (2007). Maternal education and children's academic achievement during middle childhood. Developmental Psychology, 43(6), 1497-1512. https://doi.org/10.1037/0012-1649.43.6.1497

Maika, A., Mittinty, M. N., Brinkman, S., Harper, S., Satriawan, E., \& Lynch, J. W. (2013). Changes in socioeconomic inequality in Indonesian 
children's cognitive function from 2000 to 2007: A decomposition analysis. PLOS ONE, 8(10), e78809. https://doi.org/10.1371/journal.pone.0078809

Morooka, H., \& Liang, Z. (2009). International migration and the education of left-behind children in Fujian, China. Asian and Pacific Migration Journal, 18(3), 345-370. https://doi.org/10.1177/011719680901800302

Murnane, R. J., Willett, J. B., \& Levy, F. (1995). The growing importance of cognitive skills in wage determination. The Review of Economics and Statistics, 257-266. https://doi.org/10.2307/2109863

Nguyen, C. V. (2016). Does parental migration really benefit left-behind children? Comparative evidence from Ethiopia, India, Peru and Vietnam. Social Science \& Medicine, 153, 230239.

https://doi.org/10.1016/j.socscimed.2016.02.0 21

Nobles, J. (2011). Parenting from abroad: Migration, nonresident father involvement, and children's education in Mexico. Journal of Marriage and Family, 73(4), 729-746. https://doi.org/10.1111/j.1741-

3737.2011.00842.x

Organisation for Economic Co-operation and Development [OECD].(2016). PISA 2015 Results (Volume I): Excellence and equity in education.

http://dx.doi.org/10.1787/9789264266490-en

Parrenas, P. R. (2005). Children of global migration: Transnational families and gendered woes. Stanford University Press.

Perez-Alvarez, M. (2017). Returns to cognitive skills in 7 developing countries. IZA Conference. http://conference.iza.org/conference_files/Stat istic_2018/perez_m26248.pdf

Powers, E. T. (2011). The impact of economic migration on children's cognitive development. Inter-American Development Bank (IDB). https://publications.iadb.org/publications/engli sh/document/The-Impact-of-EconomicMigration-on-Children-Cognitive-

Development-Evidence-from-the-MexicanFamily-Life-Survey.pdf

Psacharopoulos, G., \& Woodhall, M. (1987). Education for development: An analysis of investment choices. World Bank Group. http://documents.worldbank.org/curated/en/47 7701468137718173/Education-fordevelopment-an-analysis-of-investmentchoices

Reardon, S. F. (2011). The widening academic achievement gap between the rich and the poor: New evidence and possible explanations. In G. J. Duncan \& R. M. Murnane (Eds.), Whither opportunity? Rising inequality, schools, and children's life chances. Russel Sage Foundation.

Remeijers, L. (2016). The impact of parental migration on cognitive ability. Scores of China's left behind children [Tesis Magister, University of Amsterdam].

https://scripties.uba.uva.nl/document/648222

Rutter, M. (2006). Genes and Behavior: NatureNurture Interplay Explained. Balckwell, Oxford.

Rutter, M., Moffitt, T. E., \& Caspi, A. (2006). Geneenvironment interplay and psychopathology: multiple varieties but real effects. Journal of Child Psychology and Psychiatry, 47(3-4), 226-261. https://doi.org/10.1111/j.14697610.2005.01557.x

Stark, O., \& Bloom, D. E. (1985). The new economics of labor migration. The American Economic Review, 75(2), 173-178. http://www.jstor.org/stable/1805591

United Nation Children's Fund. (2007). The state of the world's children 2007: Women and children: The double dividend of gender equality. https://www.unicef.org/media/84811/file/SO WC-2007.pdf

United Nation Development Program [UNDP]. (2018). Human development indices and indicators: 2018 Statistical Update.

Wisana, I. D. G. K. (2012). Does expenditure patterns shape differently for rural household with migrants? Evidence from Indonesia Family Life Survey. Paper presented at The 11th IRSA International Conference, Banjarmasin, Indonesia.

https://www.researchgate.net/publication/3131 06661_Does_Expenditure_Patterns_Shape_Di fferently_for_Rural_Household_with_Migrant s_Evidence_from_Indonesia_Family_Life_Su rvey 
World Bank. (2010). FAQs: Early Childhood Development. Africa Region Human Development.

World Bank. (2018). World development report 2018: Learning to realize education's promise. https://www.worldbank.org/en/publication/wd r2018

Xu, Y., Xu, D., Simpkins, S., \& Warschauer, M. (2019). Does it matter which parent is absent? Labor migration, parenting, and adolescent development in China. Journal of Child and Family Studies, 28, 1635-1649. https://doi.org/10.1007/s10826-019-01382-Z

Zhang, H., Behrman, J. R., Fan, C. S., Wei, X., \& Zhang, J. (2014). Does parental absence reduce cognitive achievements? Evidence from rural China it. Journal of Development Economics, 111 , 181-195. https://doi.org/10.1016/j.jdeveco.2014.09.004

Zhao, Q., Yu, X., Wang, X., \& Glauben, T. (2014). The impact of parental migration on children's school performance in rural China. China Economic Review, 31(17), 43-54. https://doi.org/10.1016/j.chieco.2014.07.013

Zhou, M., Murphy, R., \& Tao, R. (2014). Effects of parents' migration on the education of children left behind in rural China. Population and Development Review, 40(2), 273-292. https://doi.org/10.1111/j.1728$\underline{4457.2014 .00673 . x}$ 
Jurnal Kependudukan Indonesia | Vol. 15, No. 2, Desember 2020 | 145-164 